\title{
Estimation of magnitude of various health conditions under 4Ds approach, under RBSK Programme in Devendranagar block of Panna District, Madhyapradesh, India
}

\author{
Jyoti Tiwari*, Abhishek Jain, Yaduvendra Singh, Anoop Kumar Soni
}

CHC Devendranagar, District Panna, MP, India

Received: 11 July 2015

Revised: 14 July 2015

Accepted: 16 July 2015

\section{*Correspondence:}

Dr. Jyoti Tiwari,

E-mail: drj.tiwari1@gmail.com

Copyright: (C) the author(s), publisher and licensee Medip Academy. This is an open-access article distributed under the terms of the Creative Commons Attribution Non-Commercial License, which permits unrestricted non-commercial use, distribution, and reproduction in any medium, provided the original work is properly cited.

\begin{abstract}
Background: The Rashtriya Bal Swasthya Karyakram (RBSK) aims early detection and management of the 4Ds Defects at birth, Diseases in children, Deficiency conditions and Developmental Delays including Disabilities in children in the community which are hidden may be due to unawareness or unaffordbility for treatment.

Methods: We followed the operational guidelines of 'Child Health Screening and Early Intervention Services' under RBSK. Surveys done along with RBSK team for 6 months.

Results: Total 26977 children were screened. Out of which 53 children were found to have birth defects, 434 children were found to have some kind of deficiency, 21768 children were found to have diseases and 113 children were found with developmental delay including disabilities. Globally, 200 million children do not reach their developmental potential in the first five years because of poverty, poor health, nutrition and lack of early stimulation. Here in our study $83 \%$ children deprived of good health due to 4Ds.

Conclusion: We observed that still there are many children are undiagnosed and deprived of treatment for curable diseases. Child Health Screening and promotion of Early Intervention Services is most beneficial for improvement in health status of children in rural community.
\end{abstract}

Keywords: RBSK, 4Ds, District Panna

\section{INTRODUCTION}

The Rashtriya Bal Swasthya Karyakram (RBSK) or 'Child Health Screening and Early Intervention Services' Programme under National Rural Health Mission was launched by the Ministry of Health and Family Welfare in February 2013. It aims early detection and management of the 4Ds prevalent in children. These are Defects at birth, Diseases in children, Deficiency conditions and Developmental Delays including Disabilities. ${ }^{1}$ Health screening of children is a known intervention under the School Health Programme. However, further gains can be achieved by early detection and management of conditions in all age groups. ${ }^{1}$

Out of every 100 babies born in this country annually, 6 to 7 have a birth defect. In Indian context, this would translate to 1.7 million birth defects annually and would account for 9.6 per cent of all newborn deaths. ${ }^{2}$ Various nutritional deficiencies affecting the preschool children range from 4 percent to 70 percent. Developmental delays are common in early childhood affecting at least 10 percent of the children. These delays, if not intervened timely, may lead to permanent disabilities with regard to cognition, hearing and vision. ${ }^{2}$ There are also groups of 
diseases which are very common in children e.g., dental caries, otitis media and reactive airways diseases which can be cured if detected early. It is understood that early intervention and management can prevent these conditions to progress into more severe and debilitating forms, thereby reducing hospitalisation and resulting in improved school attendance. ${ }^{2}$

The RBSK services aim to cover all children of 0-6 years of age group in rural areas and urban slums, in addition to older children up to 18 years of age enrolled in classes 1st to 12 th in Government and Government aided schools. It is expected that these services will reach and benefit about 27 crore children in a phased manner in India. ${ }^{1}$ Child Health Screening and Early Intervention Services under NRHM envisage to cover 30 identified health conditions for early detection and free treatment and management. ${ }^{1}$

\section{Identified Health Conditions for Child Health Screening and Early Intervention Services: ${ }^{1}$}

\section{Defects at Birth}

1. Neural Tube Defect

2. Down's Syndrome

3. Cleft Lip \& Palate / Cleft Palate alone

4. Talipes (club foot)

5. Developmental Dysplasia of the Hip

6. Congenital Cataract

7. Congenital Deafness

8. Congenital Heart Diseases

9. Retinopathy of Prematurity

\section{Deficiencies}

10. Anaemia especially Severe Anaemia

11. Vitamin A Deficiency (Bitot spot)

12. Vitamin D Deficiency (Rickets)

13. Severe Acute Malnutrition

14. Goiter

\section{Childhood Diseases}

15. Skin conditions (Scabies, Fungal Infection and Eczema)

16. Otitis Media

17. Rheumatic Heart Disease

18. Reactive Airway Disease

19. Dental Caries

20. Convulsive Disorders

\section{Developmental Delays and Disabilities}

21. Vision Impairment

22. Hearing Impairment

23. Neuro-Motor Impairment

24. Motor Delay

25. Cognitive Delay

26. Language Delay

\section{Behaviour Disorder (Autism) \\ 28. Learning Disorder \\ 29. Attention Deficit Hyperactivity Disorder \\ 30. Other}

District Panna of Madhyapradesh is well known for the poorest health condition in the state. IMR of Panna region is highest in the state is above $90 .^{3}$ Due to lack of awareness and poverty many of them die because of Defects at birth, Diseases, Deficiency and Developmental Delays including Disabilities. ${ }^{3}$ There is no doubt that early identification of selected health conditions by mobile health team particularly in the poor and marginalized areas is an important component of the strategy by reducing out of pocket expenditure for reaching up to hospital. This also increases the number of hidden, undiagnosed health conditions in the community which are hidden may be due to unawareness or unaffordability for treatment. Our aim is to estimate the burden of these health conditions in Devendranagar block of district Panna.

\section{METHODS}

This cross sectional survey was done along with the RBSK mobile health team to identify birth defects, deficiencies, diseases and developmental delays including disabilities in children. We screened and record the children for 6 month from $1^{\text {st }}$ August 2014 to $30^{\text {th }}$ January 2014. The Operational Guidelines of RBSK was followed with them to reach all the target groups of children for health screening. According to this, Block micro-plan for school and community visits monthly outreach plan were made based on the mapping of educational institutions and Anganwadis, and enrolment in them. The schedule of visits of Mobile Health Teams were communicated to the school, Anganwadi Centers, ASHAs, relevant authorities, students, parents and Local Government well in advance so that required preparations can be made. Anganwadi Centers and school authorities were made arrangements for prior communication with parents and motivate them to participate in the process.

1. For new born: Facility based newborn screening at public health facilities, by existing health manpower and also Community based newborn screening at home through ASHAs for newborn till 6 weeks of age during home visitation. Further ASHAs will mobilise caregivers of children to attend the local Anganwadi Centers for screening by the dedicated Mobile Health Team.

2. For children 6 weeks to 6 years: Anganwadi Center based screening by the dedicated Mobile Health Teams.

3. For children 6 years to 18 years: Government and Government aided school based screening by dedicated Mobile health teams. 
Finally data was analysed with the help of Microsoft excel.

\section{RESULTS}

Table 1: Age and sex wise distribution of screened children.

\begin{tabular}{|c|c|c|c|}
\hline $\begin{array}{l}\text { Total } \\
\text { population } \\
\text { screened in } \\
6 \text { month }\end{array}$ & Male & Female & Total \\
\hline 0-6 week & 251 & 232 & 483 \\
\hline $\begin{array}{l}\text { 6week to } \\
\text { 6year }\end{array}$ & 3567 & 3459 & 7026 \\
\hline $\begin{array}{l}\text { 6year to } 18 \\
\text { year }\end{array}$ & 8879 & 10589 & 19468 \\
\hline & 12697 & 14280 & 26977 \\
\hline
\end{tabular}

Table 1 showing the number of children screened in the period of 6 month was 26977. In which total population of 0-6 week screened in 6 month was 483, out of that male-251 female-232. Total population of 6week to 6year screened in 6 month was 7026 out of that 3567 were males and 3459 were females, and in 6year to 18 year group total screened population was 19468 in which 8879 were male and 10589 were females.

Table 2 shows the number of children found with birth defects. Total 53 children had birth defects. Out of which 22 were males and 31 were females. 2 newborns of 0 to 6 week had neural tube defect, 2 children of 6 to $18 \mathrm{yrs}$ have Down's syndrome, 5 had blindness due to congenital cataract not get operated and 4 children had congenital deafness. Proportion of NTD in screened newborn population was 4.14/1000 newborns. 3 children found to have CTEV. Total 37 children had congenital heart disease out of that 1 in 0-6 week, 19 were in 6 week to 6 year age and 17 were in 6 to 18 years age group. Proportion of congenital heart disease in total screened population was $1.37 / 1000$ population.

Table 3 shows the number of children found with deficiencies. Maximum number was of vitamin A deficiency showing Bitot spot in 257 children. Maximum 233 were in 6 to 18 year age group (9.7/1000) and more in males. Second most common deficiency found was severe acute malnutrition. 142 children were found with $\mathrm{SAM}$, in which maximum were in 6 week to 6 year age group (21/1000) and maximum were females. 30 children were found to have severe anaemia, haemoglobin $<7$ $\mathrm{mg} / \mathrm{lit} .4$ children were showing symptoms of vitamin D deficiency.

Table 4 shows the number of children found with diseases. Skin diseases was found in maximum numbers of children was $17534(64 \%)$. Second most common disease was reactive airway diseases found in 2064 (7.6\%) children. Dental carries were found in 1805
(6.8\%) children and otitis media was found in 359 children. 5 children with convulsive disorder were also found.

Table 5 shows the number of children found with developmental delay and disabilities were 113. Out of which 43 were males and 70 were females. Vision impairment found in 39 children and 5 children had hearing impairment. 9 children found with neuro-motor delay and 5 with language delay. 1 child was found with ADHD and 54 children found to have other disabilities like bed wetting etc.

\section{DISCUSSION}

Across countries and their economic status, 64.3 infants per thousand live births are born annually with birth defects. Of these, 7.9 have cardiovascular defects, 4.7 have neural tube defects. ${ }^{2}$ With a large birth cohort of almost 26 million per year, India would account for the largest share of birth defects in the world. ${ }^{2}$ Here in our study $83.3 \%$ children deprived of good health due to 4Ds.

Khalil et al., reported in their study that incidence of congenital heart disease among hospital live births in India is increasing nowadays. ${ }^{4}$ Here in my screening we found 1 newborn with CHD but in 6 weeks to $6 \mathrm{yr}$ younger 19 children and in 6 to 18 yrs age group 17 children were found with murmur in only Devendranagar block of Panna District. Two newborns out of 483 had neural tube defects accounting for 4.14/1000. Also two children of 6-18year age were found to had Down's syndrome. In a report of Verma et al., 1998 prevalence rate of 1 in 1000 was reported for Down's syndrome in India. ${ }^{5}$.

In our study Vitamin A deficiency showing bitot spot were found in 257 children in whom 233 were in 6 to 18 year age group and more in males. A report by National Institute of Nutrition, Indian Council of Medical Research reported In their data, $61 \%$ preschool children had subclinical VAD, and with this criterion, a public health problem was diagnosed in all the NNMB states surveyed, ranging from $52 \%$ in Maharashtra to $88 \%$ in Madhya Pradesh. ${ }^{6}$ Second most common deficiency found was severe acute malnutrition. 142 children were found with SAM, in which maximum were in 6week to 6 year age group and were females. In many studies it was found that over 6 percent of children less than five years of age suffer from Severe Acute Malnutrition (SAM). ${ }^{7}$ Thakur et al., also found that nutritional anaemia being a very common comorbidity of SAM requiring hospital admission. $^{8}$

Skin diseases was found to be very prevalent [64\%] in children of this block, also many children had reactive air way disease (7.6\%). Sambo et al., also found in their study that prevalence of various skin infections was $21 \%$ in rural community. ${ }^{9}$ A report by ICMR also reported median prevalence of reactive air way disease including asthma among children is reported to be 4.75 percent. $^{7}$ 
Tiwari J et al. Int J Community Med Public Health. 2015 Aug;2(3):228-233

Table 2: Distribution of children according to presence of birth defects.

\begin{tabular}{|c|c|c|c|c|c|c|c|c|c|}
\hline & & & & & & & & & \\
\hline & 0-6 wk & $\begin{array}{l}\text { 6wk- } \\
6 \mathrm{yr}\end{array}$ & $\begin{array}{l}6 y r-18 \\
\text { yr }\end{array}$ & Total & 0-6 wk & $\begin{array}{l}\text { 6wk- } \\
6 y r\end{array}$ & $\begin{array}{l}\text { 6yr-18 } \\
\text { yr }\end{array}$ & Total & Total \\
\hline $\begin{array}{l}\text { Neural Tube Defect } \\
\text { [NTD] }\end{array}$ & 1 & 0 & 0 & 1 & 1 & 0 & 0 & 1 & 2 \\
\hline Down's Syndrome & 0 & 0 & 1 & 1 & 0 & 0 & 1 & 1 & 2 \\
\hline $\begin{array}{l}\text { Cleft Lip \& Palate / } \\
\text { Cleft Palate alone }\end{array}$ & 0 & 0 & 0 & 0 & 0 & 0 & 0 & 0 & 0 \\
\hline $\begin{array}{l}\text { Talipes (club foot or } \\
\text { CTEV) }\end{array}$ & 0 & 1 & 0 & 1 & 0 & 0 & 2 & 2 & 3 \\
\hline $\begin{array}{l}\text { Developmental } \\
\text { Dysplasia of the Hip }\end{array}$ & 0 & 0 & 0 & 0 & 0 & 0 & 0 & 0 & 0 \\
\hline Congenital Cataract & 0 & 0 & 1 & 1 & 0 & 0 & 4 & 4 & 5 \\
\hline Congenital Deafness & 0 & 1 & 0 & 1 & 0 & 3 & 0 & 3 & 4 \\
\hline $\begin{array}{ll}\text { Congenital } & \text { Heart } \\
\text { Diseases } & \end{array}$ & 1 & 7 & 9 & 17 & 0 & 12 & 8 & 20 & 37 \\
\hline $\begin{array}{l}\text { Retinopathy } \\
\text { Prematurity }\end{array}$ & 0 & 0 & 0 & 0 & 0 & 0 & 0 & 0 & 0 \\
\hline & 2 & 9 & 11 & 22 & 1 & 15 & 15 & 31 & 53 \\
\hline
\end{tabular}

Table 3: Distribution of children according to presence of deficiencies.

\begin{tabular}{|c|c|c|c|c|c|c|c|c|c|}
\hline & \multicolumn{4}{|c|}{ Male } & \multicolumn{4}{|c|}{ Female } & \multirow[b]{2}{*}{ Total } \\
\hline & 0-6 wk & $\begin{array}{l}\text { 6wk- } \\
6 \mathrm{yr}\end{array}$ & $\begin{array}{l}\text { 6yr-18 } \\
\text { yr }\end{array}$ & Total & 0-6 wk & $\begin{array}{l}\text { 6wk- } \\
6 \mathrm{yr}\end{array}$ & $\begin{array}{l}\text { 6yr-18 } \\
\text { yr }\end{array}$ & Total & \\
\hline $\begin{array}{l}\text { Anaemia especially } \\
\text { Severe Anaemia }\end{array}$ & 0 & 0 & 6 & 6 & 0 & 0 & 24 & 24 & 30 \\
\hline $\begin{array}{l}\text { Vitamin A Deficiency } \\
\text { (Bitot spot) }\end{array}$ & 0 & 12 & 130 & 142 & 0 & 12 & 103 & 115 & 257 \\
\hline $\begin{array}{l}\text { Vitamin D Deficiency } \\
\text { (Rickets) }\end{array}$ & 0 & 2 & 0 & 2 & 0 & 1 & 1 & 2 & 4 \\
\hline $\begin{array}{l}\text { Severe } \quad \text { Acute } \\
\text { Malnutrition(SAM) }\end{array}$ & 0 & 60 & 0 & 60 & 0 & 82 & 0 & 82 & 142 \\
\hline Goiter & 0 & 0 & 0 & 0 & 0 & 0 & 1 & 0 & 1 \\
\hline & 0 & 74 & 136 & 210 & 0 & 95 & 129 & 223 & 434 \\
\hline
\end{tabular}

Table 4: Distribution of children according to presence of diseases.

\begin{tabular}{|c|c|c|c|c|c|c|c|c|c|}
\hline & \multicolumn{4}{|c|}{ Male } & \multicolumn{4}{|c|}{ Female } & \multirow[t]{2}{*}{ Total } \\
\hline & 0-6 wk & $\begin{array}{l}\text { 6wk- } \\
6 y r\end{array}$ & $\begin{array}{l}\text { 6yr-18 } \\
\text { yr }\end{array}$ & Total & 0-6 wk & $\begin{array}{l}\text { 6wk- } \\
6 y r\end{array}$ & $\begin{array}{l}\text { 6yr-18 } \\
\text { yr }\end{array}$ & Total & \\
\hline $\begin{array}{l}\text { Skin conditions } \\
\text { (Scabies, etc) }\end{array}$ & 3 & 2502 & 6210 & 8715 & 0 & 2232 & 6587 & 8819 & $\begin{array}{l}17534 \\
{[64 \%]}\end{array}$ \\
\hline Otitis Media & 0 & 46 & 163 & 209 & 0 & 37 & 113 & 150 & 359 \\
\hline $\begin{array}{ll}\text { Rheumatic } & \text { Heart } \\
\text { Disease } & \end{array}$ & 0 & 0 & 1 & 1 & 0 & 0 & 0 & 0 & 1 \\
\hline $\begin{array}{ll}\text { Reactive } & \text { Airway } \\
\text { Disease } & \\
\end{array}$ & 4 & 620 & 418 & 1042 & 2 & 603 & 419 & 1022 & $\begin{array}{l}2064 \\
{[7.6 \%]}\end{array}$ \\
\hline Dental Caries & 0 & 416 & 524 & 940 & 0 & 322 & 543 & 865 & $\begin{array}{l}1805 \\
{[6.8 \%]}\end{array}$ \\
\hline Convulsive Disorders & 0 & 1 & 2 & 3 & 0 & 1 & 1 & 2 & 5 \\
\hline & 7 & 3585 & 7318 & 10910 & 2 & 3195 & 7663 & 10858 & 21768 \\
\hline
\end{tabular}


Table 5: Distribution of children according to presence of developmental delays and disabilities.

\begin{tabular}{|c|c|c|c|c|c|c|c|c|c|}
\hline & \multicolumn{4}{|c|}{ Male } & \multicolumn{4}{|c|}{ Female } & \multirow[t]{2}{*}{ Total } \\
\hline & 0-6 wk & $\begin{array}{l}\text { 6wk- } \\
6 y r\end{array}$ & $\begin{array}{l}\text { 6yr-18 } \\
\text { yr }\end{array}$ & Total & 0-6 wk & $\begin{array}{l}\text { 6wk- } \\
6 \mathrm{yr}\end{array}$ & $\begin{array}{l}\text { 6yr-18 } \\
\text { yr }\end{array}$ & Total & \\
\hline Vision Impairment & 0 & 2 & 16 & 18 & 0 & 3 & 18 & 21 & 39 \\
\hline Hearing Impairment & 0 & 0 & 2 & 2 & 0 & 0 & 3 & 3 & 5 \\
\hline $\begin{array}{l}\text { Neuro-Motor } \\
\text { Impairment }\end{array}$ & 0 & 2 & 1 & 3 & 0 & 2 & 4 & 6 & 9 \\
\hline Motor Delay & 0 & 0 & 0 & 0 & 0 & 0 & 0 & 0 & 0 \\
\hline Cognitive Delay & 0 & 0 & 0 & 0 & 0 & 0 & 0 & 0 & 0 \\
\hline Language Delay & 0 & 2 & 1 & 3 & 0 & 1 & 1 & 2 & 5 \\
\hline $\begin{array}{l}\text { Behaviour Disorder } \\
\text { (Autism) }\end{array}$ & 0 & 0 & 0 & 0 & 0 & 0 & 0 & 0 & 0 \\
\hline Learning Disorder & 0 & 0 & 0 & 0 & 0 & 0 & 0 & 0 & 0 \\
\hline $\begin{array}{l}\text { Attention Deficit } \\
\text { Hyperactivity } \\
\text { Disorder[ADHD] }\end{array}$ & 0 & 0 & 1 & 1 & 0 & 0 & 0 & 0 & 1 \\
\hline $\begin{array}{l}\text { Others like bed } \\
\text { wetting etc. }\end{array}$ & 0 & 8 & 8 & 16 & 2 & 13 & 23 & 38 & 54 \\
\hline & 0 & 14 & 29 & 43 & 2 & 19 & 49 & 70 & 113 \\
\hline
\end{tabular}

In our study developmental delay and disabilities was found in 113 children. Further, Special Newborn Care Units (SNCU) Technical Reports have reported that approximate 20 percent of babies discharged from health facilities are found to suffer from developmental delays or disabilities at a later age. ${ }^{10}$ Globally, 200 million children do not reach their developmental potential in the first five years because of poverty, poor health, nutrition and lack of early stimulation. ${ }^{11,12}$ The prevalence of early childhood stunting and the number of people living in absolute poverty could be used as proxy indicators of poor development in under five children. Both of these indicators are closely associated with poor cognitive and educational performance in children and failure to reach optimum developmental potential. ${ }^{13}$ According NFHS-3 poverty and unawareness are the major factors responsible for undiagnosed cases and poor health.

\section{CONCLUSION}

With this study we observed that still there are many children are undiagnosed and deprived of treatment for curable diseases and later that will lead to some kind of disabilities. And this hidden part of children with defects, diseases or deficiencies constitutes major part in child mortality. Any effective health intervention will reduce both direct costs and out-of-pocket expenditure as here, Child Health Screening and promotion of Early Intervention Services is more important for improvement in health status of children in rural community. It will also very helpful in reducing the extent of disability, in improving the quality of life and enabling all persons to achieve their full potential. The beautiful feature of the RBSK Services is the continuum of care extending over different phases of the life of a child over the first 18 years. I sincerely hope that the States would give utmost priority to RBSK together with several other reproductive and child health initiatives under NRHM and thereby improve both survival and development of children.

Funding: No funding sources

Conflict of interest: None declared

Ethical approval: The study was approved by the hospital ethics committee

\section{REFERENCES}

1. Operational guidelines Rastriya Bal swasthya karyakram (RBSK) Child Health Screening and Intervention Services under NRHM, Ministry of Health and Family welfare, Feb 2013.

2. Christianson A, et al. March of Dimes Global Report on birth defects. The hidden toll of dying and disabled children, 2006.

3. Annual Health survey, Madhya Pradesh, 2011-2012.

4. Khalil A, Aggarwal R, Thirupuram S, Arora R. Incidence Of Congenital Heart Disease Among Hospital Live Births In India. Indian J Pediatric. 1994;31:519-27.

5. Verma IC, Mathew S, Elango R, Shukla A. cytogenetic study in Down's syndrome, Indian Pediatr. 1998;28:991-6.

6. Prevalence of Vitamin A Deficiency among Rural Preschool Children. Hyderabad, India: National Institute of Nutrition, Indian Council of Medical Research. Report No 23; 2006.

7. Indian Council for Medical Research (ICMR), 2006.

8. Thakur N, Chandra J, Pemde H, Singh V. Anemia in severe acute malnutrition. IJP. 2014;30(4):440-2.

9. Sambo MN, Idris SH, Umar AA, Olorukooba AA. Prevalence of scabies among school-aged children in Katanga rural community in Kaduna state, Northwestern Nigeria. Annals of Nigerian Medicine. 2012;6(1):26-9. 
10. Technical reports on Operational Status of SNCUs in India, ministry of health and family welfare, 2012.

11. Lancet series on Child Development in developing country, September 23, 2011.

12. Kamble M1, Chatruvedi P. Epidemiology of sickle cell disease in a rural hospital of central India. Indian Pediatr. 2000;37(4):391.

13. Nair MK, George B, Padmamohan J, Sunitha RM, Resmi VR, Prasanna GL, et al. Developmental delay and disability among under--5 children in a rural ICDS block. Indian Pediatr. 2009;46:s75-8.

14. National Family Health Survey - 3 (NFHS-3), 2005-06.

Cite this article as: Tiwari J, Jain A, Singh Y, Soni AK. Estimation of magnitude of various health conditions under 4Ds approach, under RBSK Programme in Devendranagar block of Panna District, Madhyapradesh, India. Int J Community Med Public Health 2015;2(3):228-33. 